\title{
Vpliv ozelenjenih fasad na zaznavanje urbanih okolij - primerjava med Slovenijo in Nizozemsko
}

$\mathrm{V}$ splošni javnosti in v raziskavah $\mathrm{v}$ raznih strokah pridobivajo ozelenjeni fasadni ovoji stavb vse večjo pozornost. Sistemi vertikalnih ozelenitev imajo pomembno vlogo kot izrazni element stavbe, hkrati pa se obravnavajo kot poseben tip zelene infrastrukture $\mathrm{z}$ raznovrstnimi pozitivnimi učinki predvsem na gosto pozidanih urbanih območjih. Raziskava se osredotoča na zaznavo ozelenjenih fasad v urbanih ambientih. Poudarek je na vizualnem zaznavanju in dojemanju prijetnosti ali vizualne kakovosti raznovrstnih prostorov glede na to, ali stavba ima ozelenjeno fasado ali ne. Odnos javnosti in vrednotenje urbanega odprtega prostora s proučevanimi zelenimi elementi smo preverjali na Nizozemskem in v Sloveniji. V spletno anketo so bili vključeni prikazi prostorskih situacij, o katerih so anketiranci izrazili mnenje. Ciljni skupini sta bili širša javnost in študenti arhitekturno-urbanističnih smeri. Kljub splošnemu rezultatu o večji prijetnosti bolj zelenega mestnega okolja, ki kaže na to, da večina ljudi tudi vertikalne ozelenitve dojema kot prispevek h kakovosti urbanih ambientov, se med proučevanima skupinama $\mathrm{v}$ posamezni državi pojavljajo razlike.

Ključne besede: vertikalne ozelenitve, ozelenjene fasade, žive stene, zaznavanje urbanega prostora, zelena infrastruktura 


\section{Uvod}

Zavedanje o pomenu naravnih prvin $\mathrm{v}$ mestih se zaradi prepoznanih okoljskih problemov in sprememb, ki vplivajo tudi na bivalno kakovost $\mathrm{v}$ urbanih naseljih, povečuje tako v strokovni kot splošni javnosti. Sodobne strategije načrtovanja urbanega prostora vključujejo te, vedno bolj izpostavljene tematike. $\mathrm{Ne}$ osredotočajo se samo na vgradnjo trajnostnih materialov, ampak je v njih zajet tudi rezultat razmisleka o predvidenih naravnih procesih, ki lahko pripomorejo $\mathrm{k}$ izboljšanju grajenega okolja, od zagotavljanja večjega deleža zelenih površin, uporabe drevja, do ozelenjevanja stavb, pri čemer se v obstoječih gosto pozidanih delih mest poudarja uporaba rastlinskega gradiva pri oblikovanju zunanjega ovoja stavb (Medl idr., 2017). Sistemi vertikalnih ozelenitev in zelenih streh so elementi zelene infrastrukture in del zelenega sistema mesta ali naselja (Šuklje Erjavec idr., 2020), saj izvajajo nekatere funkcije zelenega sistema (ekološke, okoljske, podnebne, oblikovne, kulturne, strukturne, gospodarske in družbene). Čeprav so se stavbe ozelenjevale že v preteklosti, postajajo zelene strehe in stene $\mathrm{v}$ sodobnem času sinonim za inovativno obliko urbanega ozelenjevanja, še zlasti v velikih mestih, kjer prevladuje toplejše in vlažno podnebje (Wong idr., 2010a). Predvsem v azijskih mestih se krepijo ideje o biofiličnem urbanizmu in oblikovanju vertikalnih in gozdnatih mest (Guan idr., 2018). $\mathrm{V}$ medijih se s predstavljanjem raznih primerov vključevanja rastlin $\mathrm{v}$ arhitekturo promovira uporaba teh povsod po svetu (Černigoj, 2018). Ker je uporaba biološko-tehničnih sistemov ovojev stavb pogojena s podnebnimi razmerami, rezultati raziskav niso nujno prenosljivi v druge okoliščine in primerljivi med državami. Zaznavanje zelene infrastrukture $\mathrm{v}$ mestih so proučevali na primer z grško javnomnenjsko raziskavo (Tsantopoulos idr., 2018). Rezultati kažejo, da je estetski vidik ozelenjevanja stavb v Atenah v zavesti ljudi veliko bolj pomemben in razširjen kot njihov vpliv na izboljšanje mikroklime in okoljskih parametrov. Z malezijsko raziskavo (Mansor idr., 2017) pa so ugotovili, da prebivalci vertikalne ozelenitve dojemajo kot del ulične umetnosti z nekim okoljskim učinkom in ga zaradi te značilnosti tudi visoko vrednotijo. Glede na ugotovitve raziskav iz krajev, kjer prevladuje toplejše podnebje, nas zanima, kakšna sta zaznavanje in splošen odnos javnosti do ozelenjenih fasad $\mathrm{v}$ evropskem zmerno toplem podnebnem pasu. $\mathrm{V}$ tej raziskavi se proučuje zaznavanje uporabnikov prostora iz Nizozemske in Slovenije.

\subsection{Ozelenjene fasade kot integralni del arhitekture}

Vertikalne ozelenitve se pojavljajo na različnih tipih stavb, $v$ različnih prostorskih kontekstih in $\mathrm{v}$ raznovrstnih izvedbah. Način vključevanja zelenih prvin $\mathrm{v}$ stavbni ovoj je običajno povezan $\mathrm{z}$ arhitekturnim in oblikovalskim konceptom posamezne stavbe. Celotni stavbni ovoj, še posebej fasada, ima namreč izrazno vlogo. $V$ srednjeevropskem prostoru se bolj množično ozelenijo strehe, manj fasade. Redki so primeri sodobne arhitekture s popolnoma ozelenjenim stavbnim ovojem, kot primer na Nizozemskem (Internet 4). Vgradnja primernega vegetacijskega sistema je tesno povezana $s$ specifičnimi podnebnimi in mikrolokacijskimi razmerami, ki vplivajo na izbor materialov. $V$ prvi fazi načrtovanja je treba za doseganje želenih oblikovalskih ciljev določiti zasnovo in tip vertikalne ozelenitve ter njeno vzdrževanje. Rezultati singapurske raziskave o ozelenjenih fasadah so pokazali, da lahko pomanjkanje tehničnih informacij, navodil za vzdrževanje in informacij o rastlinah postane ovira za izvedbo teh sistemov (Wong idr., 2010b), čeprav ti veljajo za potencial $\mathrm{v}$ arhitekturi in gradnji prihodnosti. Podobno jih obravnavajo italijanski raziskovalci. Perinijeva in Rosasco (2013) sta analizirala stroške in koristi ozelenjenega ovoja stavb. Proučevala sta vpliv na stavbo in okolico, predvsem z vidika okoljskih, gospodarskih in družbenih izboljšav, poleg tega sta z raziskavo opozorila na težavnost opredelitve učinkov teh gradnikov na zunanji prostor.

Opredelitev ozelenjenih fasad, ki jo uporabljamo v tej raziskavi, je bila oblikovana na podlagi pregleda terminologije številnih raziskav (Jim, 2015; Pfoser, 2016; Bustami idr., 2018) in razlaga ozelenjene fasade ali zelene stene kot vertikalne sisteme z rastlinami, neposredno ali s podpornim sistemom integrirane v zunanjo steno (ovoj) stavb. Tipologija vertikalnih ozelenitev je raznovrstna. Določajo jo konstrukcijski elementi, način vgradnje rastlin in izbor teh. Kljub različnim pristopom $\mathrm{k}$ opredelitvi teh elementov se na podlagi značilnosti opredeljujeta dva osnovna tipa: zelene fasade (ang. green facades) in žive stene (ang. living walls). Za zelene fasade sta značilna stik $s$ tlemi ali izraščanje rastlin iz tal in uporaba popenjavk, ki se vzpenjajo po steni ali ob njej, za žive stene pa je značilno, da se ob steno pritrdi element, iz katerega rastline rastejo (in nimajo stika s tlemi) (Bustami idr., 2018). Ker so ti vertikalni sistemi vedno vezani na steno objekta, soustvarjajo tesno povezavo med grajenimi in naravnimi gradniki. Načelo združevanja kontrastnih prostorskih entitet ima vpliv na opazovalca ali uporabnika zadevnega prostora.

\subsection{Zaznavanje urbanega prostora}

Proučevanje urbanega okolja in izkušnja mestnega prostora sta predmet mnogih raziskav. $V$ primeru proučevanja ozelenjenih fasad stavb se sociološko-psihološki vidik prepleta z drugimi vidiki, ki vplivajo na zaznavanje in javno mnenje (Köhler, 2008). Zaznavanje je postopni (fazni) proces, ki vključuje vsa čutila. Bell navaja tri faze zaznavanja. Prva je zaznavna faza prejemanja dražljaja, v kateri se vzpostavi povezava z dražljajem, druga je faza obdelave in organiziranja informacij, pri čemer imajo 
pomembno vlogo izkušnje prejemnika dražljaja, tretja je faza kognitivnega procesa ali osmišljanja ter vključuje interpretacijo in vrednotenje, poleg tega je povezana $s$ kulturološkim in socialnim ozadjem posameznika (Bell, 2001). Zaznavanje arhitekture, grajenega okolja in odprtega prostora temelji na intermodalnem zaznavanju, pri katerem poteka zaznavanje v kombinaciji več čutil. Velika večina informacij, približno 70 \% vseh, je pri tem pridobljena z vidom (Fieandt, 1966). Avtorji trdijo, da je treba prostor in arhitekturo osebno izkusiti (Rasmussen, 2001), naše zaznavanje prostora je namreč večplastno, povezano tako $s$ fizičnimi in funkcionalnimi prostorskimi značilnostmi kot pomeni. Kompleksno razlago sta na podlagi Relphovega dela (1976) razvila Punter (1991) in Montgomery (1998) (v Carmona idr., 2003). Za potrebe urejanja mestnega prostora sta opredelila tri vidike, ki opišejo t. i. kraj - ta se vzpostavi kot rezultat odnosa med fizičnimi značilnostmi prostora, dejavnostmi, ki potekajo v njem, in simbolnimi pomeni, ki mu jih pripisujejo uporabniki. Preplet teh vidikov pomembno vpliva na dojemanje hierarhične umeščenosti posameznega odprtega javnega prostora v mestno strukturo.

Kulturološki vidik dojemanja prostora dokazujejo številne študije. Passini (1992) izpostavlja povezavo med vzorci dojemanja okolja in potrebo ali zmožnostjo ljudi, da se okolju prilagodijo - če je (mora biti) zadevna kulturna sredina v stiku z naravo ali naravnimi procesi, je njeno dojemanje prostora kompleksnejše. Evropski avtorji ugotavljajo, da je v evropski kulturi dojemanje prostora vezano predvsem na fizično ureditev prostora (Jackson, 1994; Nikšič, 2008), kar razlagajo $\mathrm{z}$ večplastno fizično zgradbo evropskih mest, ki so se v stoletjih razvijala $\mathrm{z}$ različnimi in prepoznavnimi morfološkimi oblikami. Ameriške študije pa kažejo, da prebivalci nekega kraja ne povezujejo toliko z njegovo arhitekturno podobo ali oblikovanostjo prostora, ampak bolj z dogajanji in dogodki v njem. Podobno Rapoport (1977) razlikuje med t. i. zahodno in prvobitnimi kulturami, ko ugotavlja, da v zahodni kulturi prostor dojemamo predvsem na podlagi njegovih fizičnih in funkcionalnih značilnosti, pripadniki prvobitne kulture, npr. avstralski aborigini, pa prostor dojemajo na podlagi mitoloških pomenov in simbolov. Na Slovenskem je na področju urbanističnega oblikovanja temeljnih zaznavnih študij zelo malo. Nikšič (2008) ugotavlja, da na zaznavo javnih odprtih prostorov mest najbolj vplivajo fizične značilnosti prostora, pomemben vpliv imajo tudi funkcijske značilnosti, vloga simbolnih pomenov pa je majhna.

\subsection{Zelene prvine $v$ urbanih ambientih}

Zaznavanje zelenih prvin v sklopu urbanističnega oblikovanja težko obravnavamo zunaj prostorskega konteksta. Namen te raziskave je proučitev odnosa ljudi do urbanih ambientov glede na prisotnost ozelenjenih fasad v njih. Sklepamo, da ozelenjene fasade vplivajo na zaznavanje prostora, v katerega so umeščene. Kot zeleni gradnik s svojimi fizičnimi značilnostmi vplivajo na odnos med volumni in prazninami, merilom, proporci, ploskvami, teksturami, ritmi v prostoru in materialno (ne)enotnostjo ipd. Hkrati so pomembni pomenska razmerja med naravnim in grajenim ter različne interpretacije trajnostnega vidika in splošnega odnosa do naravnih prvin v urbanem okolju.

Zaznavanje urbanega okolja in naravnih prvin $\mathrm{v}$ njem se $\mathrm{v}$ raziskavah proučuje na različne načine. Raziskave o integraciji narave $\mathrm{v}$ oblikovanje se osredotočajo na človeka in njegovo potrebo po zaznavanju naravnih procesov $\mathrm{v}$ prostoru in času (Hayles in Aranda-Mena, 2018) ter povezanost vplivov naravnih prvin, predvsem rastlin, $\mathrm{v}$ vsakodnevnem doživljanju okolja, s stopnjo uporabe tega prostora. Ozelenjenost ulic ima na primer dokazano velik vpliv na hodljivost $\mathrm{v}$ mestih in $s$ tem na telesno aktivnost prebivalcev (Lu idr., 2018). Velik pozitivni učinek rastlin na zaznavanje ugotavljajo tudi v raziskavi problematike hrupa v urbanem okolju (Van Renterghem, 2019). Vizualno zaznavanje rastlin namreč omili zaznavo neprijetnega zvoka, zato so ozelenjeni prostori kljub hrupu zaznani kot bolj prijetni kot tisti brez rastlin. Glede ozelenjenosti stavbnega ovoja sta Whitova in Gaterslebnova (2011) proučevali, ali so ozelenjene stavbe (z zelenimi strehami in stenami) bolj cenjene od neozelenjenih, in ugotovili nekaj prednosti v korist ozelenjenih stavb. $V$ raziskavah zaznavanja in mnenja javnosti se tudi na področju prostorskega načrtovanja pogosto uporabljajo vprašalniki s pripravljenimi primeri prisotnosti in odsotnosti nekega dražljaja. Podobno se uporabljajo dražljaji (negativni in pozitivni) tudi v drugih strokah, na primer pri proučevanju zaznavnih fizioloških procesov, pri merjenju možganskega odziva ali aktivnosti v hemisferah (O'Hare idr., 2017).

Hipotetično izhodišče te raziskave je, da ljudje urbane prostore, ki vključujejo rastline, zaznavajo kot bolj prijetne (všečne). Namen raziskave je preveriti tezo na podlagi obravnave zelenih sten kot elementov zelene infrastrukture v urbanem okolju. Ključna vprašanja, ki se v zvezi s tem pojavljajo, so:

- Ali na zaznavanje prijetnosti ambientov vpliva prisotnost rastlin na fasadah?

- Ali ima količina ozelenjenosti vpliv na oceno prijetnosti ambienta?

- Ali imajo ljudje preference do nekaterih tipov fasadne ozelenitve?

Osrednji del te raziskave je namenjen proučevanju odziva ljudi in razlik med njihovimi odgovori. Poleg mnenj javnosti obravnavamo tudi mnenje izbranih skupin. $Z$ raziskavo se ne odpirajo le vprašanja o zaznavanju vertikalnih ozelenitev, ampak tudi o tem, katere posamezne tipe odprtih prostorov in katere njihove fizične značilnosti, ki vplivajo na to, ali so bolj ali manj privlačni, bi ljudje prednostno izbrali. 


\section{Raziskovalne metode \\ 2.1 Oblikovanje vprašalnika}

Za zbir mnenja javnosti smo uporabili metodo anketiranja. Pri oblikovanju vprašalnika in pripravi materiala za anketo so se upoštevali načeli čim večje merljivosti odgovorov (pridobitev neodvisnih ocen) in ustrezne reprezentativnosti predstavljenega materiala ter zagotavljanje jasnega razumevanja vprašanj in uporabnikom čim bolj prijazna uporaba (obseg ankete). Pripravljen je bil javno dostopen spletni vprašalnik $\mathrm{v}$ slovenskem in angleškem jeziku. Spremno besedilo v uvodu je anketirance seznanilo $z$ anonimnostjo ankete, namenom zbiranja podatkov ter vsebino in obsegom ankete, podano je bilo priporočilo o uporabi računalniškega zaslona, med drugim funkcij povečave za prikaz slik v primeru uporabe na manjših napravah (npr. pametni telefon). Anketo so sestavljala vprašanja, vezana na prikaze urbanih situacij (vizualne dražljaje), in vprašanja za zajem splošnih socialno-demografskih podatkov. Poleg splošnih vprašanj (spol, starost, izobrazba, država bivanja, poklic) so bila vključena dodatna vprašanja za razumevanje možnega vpliva na presojo preferenc anketirancev, na primer njihovo bivalno okolje.

Anketiranci so za vsak slikovni prikaz podali oceno privlačnosti urbanega ambienta na lestvici od -10 (neprivlačno) do 10 (zelo privlačno), odgovore so označili z drsnikom. Slikovno gradivo obsega prikaze dvajsetih prostorskih situacij (raznovrstnih urbanih prostorov) $v$ treh različicah istega prostora. Vseh šestdeset slik (dražljajev) je bilo v vprašalniku razvrščenih po vnaprej določenem mešanem vrstnem redu. Sosledje različnih urbanih prostorov in variant ozelenitev je bilo vzpostavljeno tako, da je bilo možno čim manjše medsebojno sovplivanje posameznih dražljajev. Ne glede na zavedanje o učinku začetnih in končnih prikazov pri uporabi anket $s$ slikovnim gradivom (Strumse, 1994) niso bile dodane dodatne slike, ki bi se pozneje v analizi izključile, saj je bilo skupno uporabljenih zelo veliko slik (dodatni prikazi bi povečali obseg ankete).

\subsection{Vizualni dražljaji}

Slikovne prikaze prostorskih situacij smo pripravili tako, da bi bili v prihodnje lahko uporabni tudi za obdelavo z drugimi metodami in primerjanje rezultatov. Pripravljeno slikovno gradivo smo obdelali na enoten način in ga v vprašalnik vključili tako, da so se anketiranci lahko osredotočili na posamezen dražljaj. Raziskava se ni ukvarjala s spreminjanjem grajenega okolja in arhitekture na prikazih, simulacije so prikazovale le spremembe proučevanih elementov - ozelenjenih fasad. $Z$ vidika proučevanja urbanega prostora smo izbrali različne urbane ambiente in možnosti vertikalnih ozelenitev v njih. Posamezni odprti prostor je bil prikazan $\mathrm{v}$ treh različicah: (A) brez ozelenitve, (B) z zmerno - delno ozelenitvijo fasad(-e) in (C) z gosto - polno ozelenitvijo fasad(-e). Slike z vertikalnimi ozelenitvami so glede na tipologijo prikazovale tip zelene fasade (22 prikazov) ali tip žive stene (18 prikazov).

Za prikaz raznovrstnih urbanih prostorov so se uporabile fotografije realnega stanja in obdelane fotografije teh realnih stanj $\mathrm{v}$ dveh različicah. Malo so bile uporabljene tudi 3D-vizualizacije. Glede na proučevani vidik uporabnika prostora smo uporabili slike z očiščca pešca ali v merilu uporabnika prostora. Namensko smo izbrali prikaze z vidnim prostorskim kontekstom, ki je ključen za razumevanje prostora, proučevanega gradnika in prostorskih razmerij (npr. bližnji prikazi in prikazi od daleč), da se lahko anketiranec vrednostno opredeli do zadevnega ambienta (poda mnenje o pojavnosti zelene stene $\mathrm{v}$ tem okolju). Izbrane so bile slike, na podlagi katerih lahko opazovalec sklepa o rabi zunanjega prostora (npr. prisotnost ulice, parkirišča, igriščca itd.) in tipu stavbe ali rabi stavbe (glede na njeno pojavnost: stanovanjska, industrijska, trgovska, javni program). Izbrani primeri, vključeni v anketo, so bili: javni odprti prostori ( 6 primerov), prostori ob stavbah z javnim programom (7 primerov), stanovanjska območja (5 primerov) in poslovno-industrijska območja (2 primera). Glede na fizične in programske značilnosti prikazanega prostora smo te primere prostorov obravnavali kot podrobnejše prepoznavne tipe:

- odprti prostori kot ulični prostori (primarno pretočni ambienti) in večnamenski prostori z drugimi vrstami rabe odprtega prostora, vezanimi na aktivnosti in zadrževanje ljudi (npr. trg, igrišče),

- prostori ob javnih objektih različnega tipa (prikaz stavbe z javnim programom, upoštevana je tudi možnost druge interpretacije), prikaz obšolskega prostora ali prostora ob izobraževalni ustanovi ter v posebni skupini prikazi vizualizacij načrtovane gradnje,

- prostori območij stanovanjske gradnje (realne situacije in vizualizacije večstanovanjskih stavb),

- prostori nakupovalnih središč (tipični objekti večjega merila).

Osnova slikovnega gradiva so bile terenske avtorske fotografije in vizualizacije (3D-prikazi) drugih avtorjev, pri tem so bile uporabljene tudi spletne fotografije (Vogelnik, 2013; Internet 1; Internet 2; Internet 3; Haesevoets, 2015). Pri pripravi obdelanih slik ali slikovnih simulacij (fotomontaž) smo uporabili program za digitalno obdelavo rastrskega slikovnega gradiva Adobe Photoshop CS3. Pri obdelavi slik je bil poudarek na spreminjanju fasadnega ovoja osnovnega slikovnega gradiva. Za namen izključevanja vpliva drugih dejavnikov na presojo posameznih slik se z njihovo obdelavo ni posegalo $\mathrm{v}$ prikazovanje drugih prostorskih prvin niti se ni posegalo $\mathrm{v}$ arhitekturo stavbe (niso se prilagajali nobeni drugi arhitekturni elementi), prikaz oseb na slikah je bil poenoten (ljudje so bili na vseh slikah v približno enakem številu). 


\section{Povprečja in standardni odkloni}

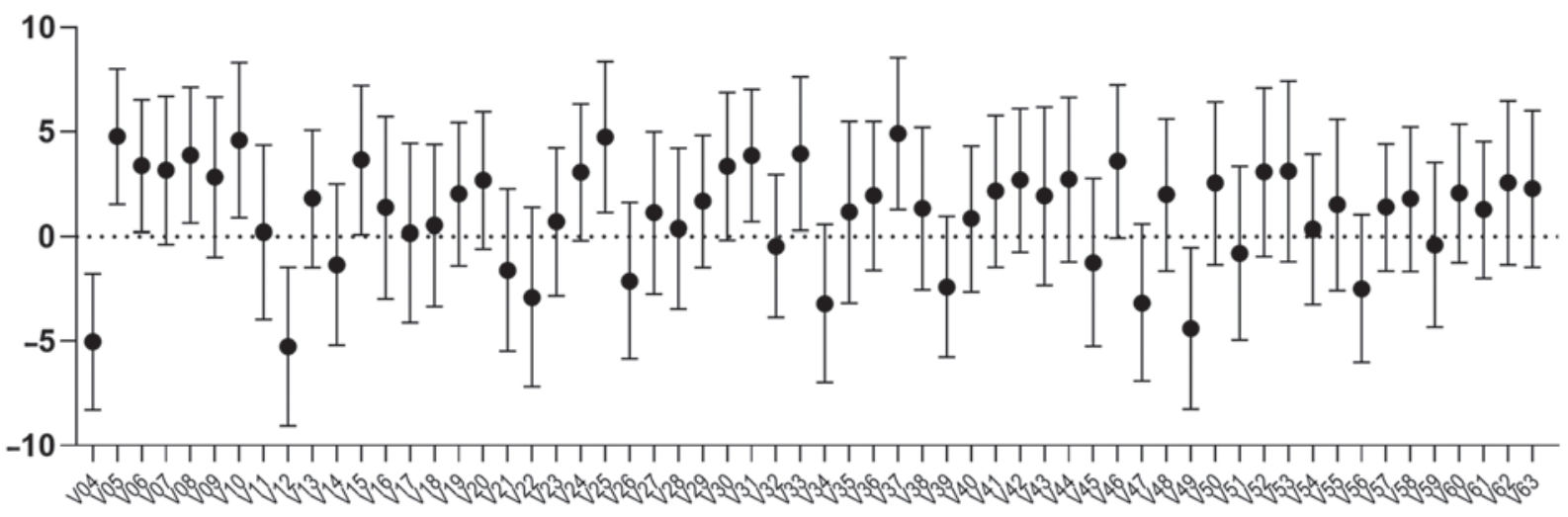

Slika 1: Prikaz povprečij ocen in SD za vseh 60 slik anketi $(n=223)$ (izdelala: Jana Kozamernik)

\subsection{Potek zbiranja informacij}

Anketiranje je potekalo s spletnim orodjem 1KA spletne ankete Centra za družboslovno informatiko Univerze v Ljubljani. Anketa je bila izvedena na Nizozemskem in v Sloveniji v poletnih mesecih leta 2019 (od junija do septembra). Da bi pridobili čim večji reprezentativni vzorec, je bilo povabilo $\mathrm{k}$ sodelovanju v anketi po e-pošti poslano na številne e-naslove v obeh ciljnih državah. K izpolnjevanju ankete smo vabili tudi z osebnimi vabili, tega je bilo malo in vabili smo predvsem starejše. Anketiranje se je osredotočalo na pridobitev podatkov za dve skupini - splošno javnost in mlajšo generacijo strokovne javnosti. Zajem naključnega vzorca splošne javnosti je vključil osebe, ki niso strokovno povezane $\mathrm{z}$ arhitekturno in urbanistično stroko. Vzorčenje druge skupine je potekalo med študenti arhitekturno-urbanističnih smeri, delno je vključevalo tudi sorodne stroke (na primer krajinsko arhitekturo). Da bi zagotovili reprezentativnost strokovne skupine, smo vanjo vključili študente različnih letnikov in študijskih smeri. Podatke smo želeli pridobiti za vse starostne skupine, čim bolj raznovrstno strukturo prebivalstva in raznovrstne profile glede na delovno področje.

\subsection{Analiza podatkov}

Statistične izračune smo izvedli z uporabo programa IBM SPSS Statistics za Windows v kombinaciji z Microsoft Excelom in programom GraphPad Prism 8.3.0. Pridobljene veljavne podatke obeh anket (izvorno vzorčenih v Sloveniji in na Nizozemskem) smo združili v skupno bazo, iz katere smo naknadno izločili neustrezne vprašalnike (nedokončane ankete, ankete z manjkajočimi odgovori na vprašanja in ankete z neocenjenimi slikovnimi prikazi) in napake. Pridobljenih je bilo 223 veljavnih anket, 131 slovenskih in 92 nizozemskih. V osnovni izračun prvega, slikovnega dela ankete (prikazi slik in ocenami $z$ drsno ročico) smo vključili povprečja in standardne odklone (razpršenost porazdelitve vrednosti), natančnejšo analizo slikovnih prikazov pa smo izvedli s primerjavo frekvenčne porazdelitve ocen posamezne slike. Analizo smo izvajali na podlagi proučevanja oblikovanih kazalnikov:

- razmerje med grajenim in zelenim; tri različice variantnih prikazov ambienta smo označili kot sklope A (brez ozelenjene fasade), B ( $\mathrm{z}$ delno ozelenjeno fasado) in $\mathrm{C}(\mathrm{s}$ polno ozelenjeno fasado),

- tip vertikalnega sistema ozelenjevanja; glede na osnovna tipa zelene fasade (ZF) in žive stene (ŽS),

- tip urbanega prostora; odprti prostor $\mathrm{z}$ večnamensko funkcijo ali s prevladujočimi vrstami rabe, kot je trg, igrišče ipd. (Oo), ulični ali obcestni odprti prostor $(\mathrm{Os})$, prostor ob javnih objektih (Pi), prostor ob javnem objektu šoli (Ps), prostor ob javnem objektu - 3D-prikaz (Pr), stanovanjsko območje $(\mathrm{R})$, stanovanjsko območje - mogoča tudi druga interpretacija (Ri), stanovanjsko območje - 3D-prikaz (Rr) in prostor v poslovno-trgovskem območju (S).

\section{Rezultati}

\subsection{Demografske značilnosti}

$\mathrm{Na}$ anketo je odgovorilo 58,7 \% žensk in 41,3\% moških. V obeh državah anketiranja so bili vključeni ljudje različnih starostnih skupin, prevladovali so skupina delovno aktivnega prebivalstva in mladi. Največ anketirancev je spadalo v skupino do 25 let (50,6\%), številčno so sledili anketiranci starostne skupine od 26 do 35 let, katerih delež je bil 19,3\%, delež skupine od 36 do 50 let je bil 15,7\%, delež skupine od 51 in 65 let je bil 10,8\%, delež starejših od 65 let pa 3,6\%. Glede na izobrazbeno raven je $24,2 \%$ anketirancev doseglo VI. izo- 


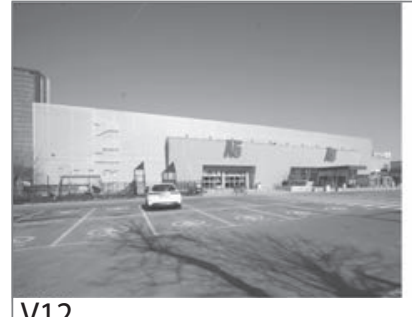

V12

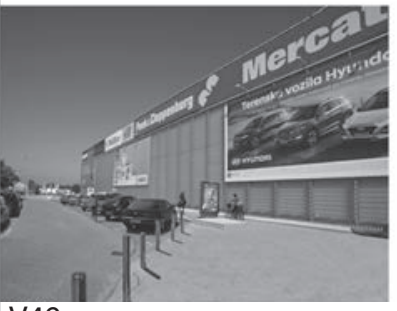

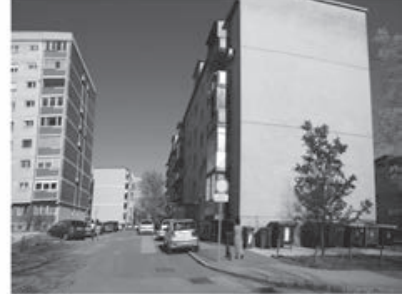

V04

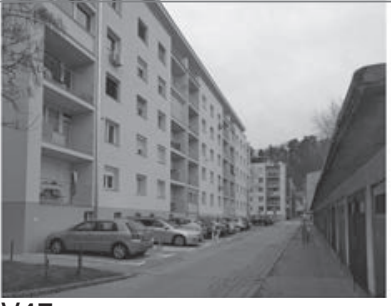

V47

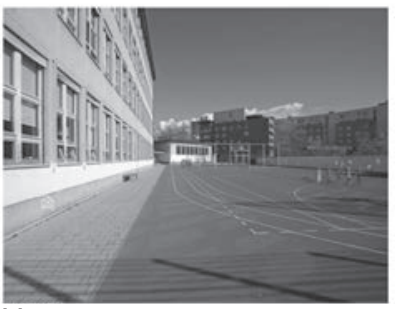

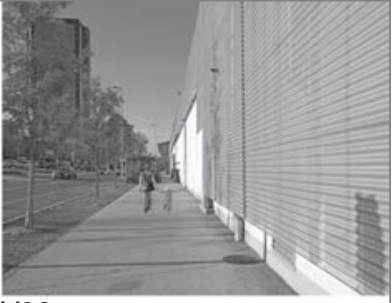

V22

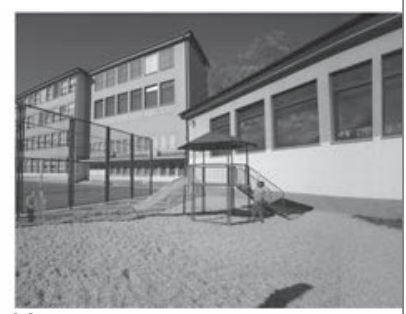

V39

V49 V34

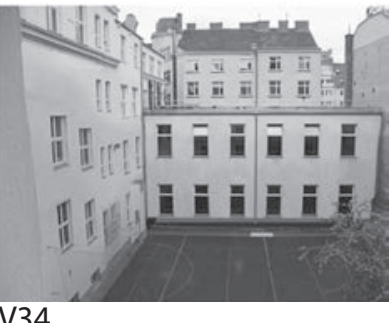

Preglednica 1: 10 (od 60) najslabše ocenjenih prikazov glede na povprečne ocene $(n=223)$

\begin{tabular}{lllllllllll}
\hline Slika* & V12 & V4 & V49 & V34 & V47 & V22 & V56 & V39 & V26 & V21 \\
\hline Povprečna ocena & $-5,26$ & $-5,03$ & $-4,40$ & $-3,22$ & $-3,17$ & $-2,90$ & $-2,49$ & $-2,41$ & $-2,12$ & $-1,61$ \\
\hline P(1-20)** & 1 & 11 & 17 & 15 & 8 & 2 & 10 & 9 & 7 & 17 \\
\hline A/B/C & A & A & A & A & A & A & A & A & A & B \\
\hline Urbani prostor (tip) & S & R & S & Ps & R & Os & Ps & Ps & Os & S \\
\hline Zelena stena (tip) & / & $/$ & $/$ & $/$ & $/$ & $/$ & $/$ & $/$ & $/$ & ŽS \\
\hline
\end{tabular}

* Slika v vprašalniku (vrstni red). ** Izbrani primer (fotografija, vizualizacija).

Slika 2: Prikazi z najslabšimi povprečnimi ocenami $(n=223)$ (izdelala: Jana Kozamernik)

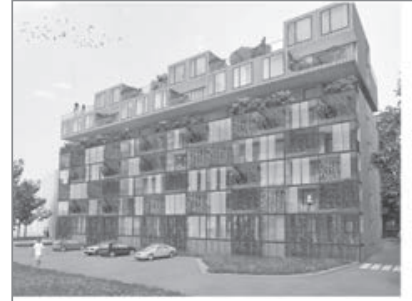

V37

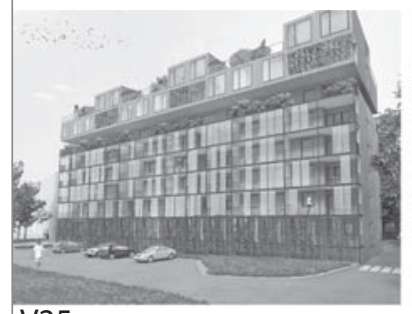

V25

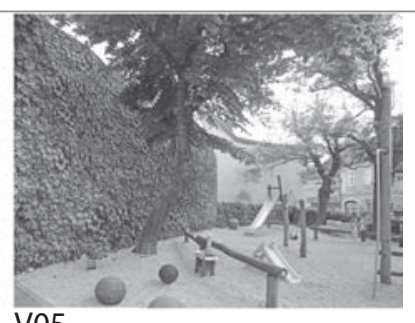

V05

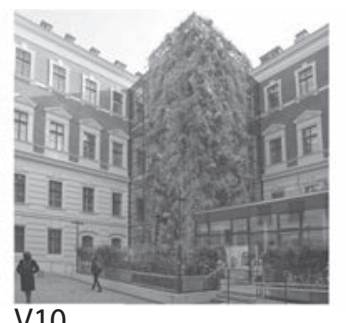

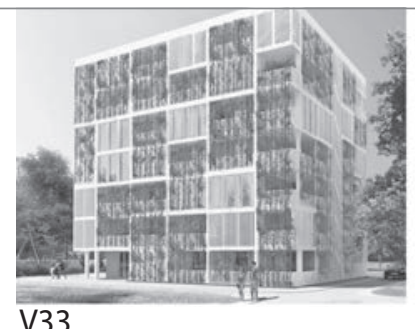

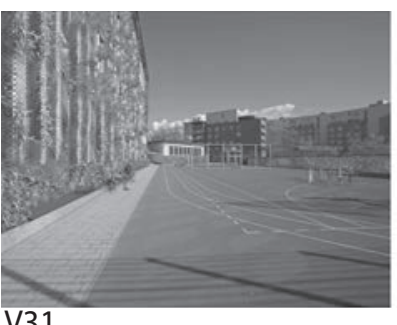

V31

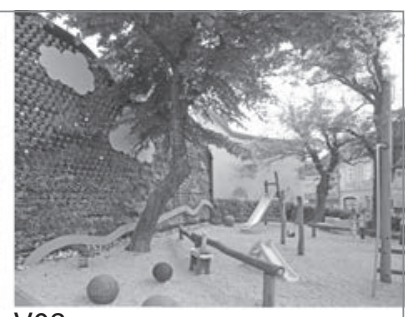

V08

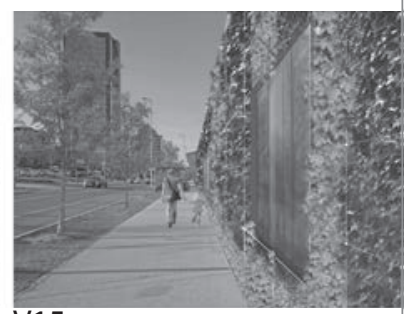

V15

Preglednica 2: 10 (od 60) najbolje ocenjenih prikazov glede na povprečne ocene ( $n=223$ )

\begin{tabular}{lllllllllll}
\hline Slika & V37 & V5 & V25 & V10 & V33 & V8 & V31 & V15 & V46 & V6 \\
\hline Povprečna ocena & 4,91 & 4,77 & 4,74 & 4,59 & 3,95 & 3,87 & 3,86 & 3,65 & 3,59 & 3,37 \\
\hline $\mathrm{P}(1-20)$ & 5 & 18 & 5 & 14 & 6 & 18 & 10 & 2 & 4 & 10 \\
\hline A/B/C & $\mathrm{C}$ & $\mathrm{C}$ & $\mathrm{B}$ & $\mathrm{C}$ & $\mathrm{B}$ & $\mathrm{B}$ & $\mathrm{C}$ & $\mathrm{C}$ & $\mathrm{B}$ & $\mathrm{B}$ \\
\hline Urbani prostor (tip) & $\mathrm{Rr}$ & $\mathrm{Oo}$ & $\mathrm{Rr}$ & $\mathrm{Pi}$ & $\mathrm{Rr}$ & Oo & $\mathrm{Ps}$ & Os & $\mathrm{Ri}$ & $\mathrm{Ps}$ \\
\hline Zelena stena (tip) & ZF & ZF & ZF & ZF & ZF & ŽS & ZF & ZF & ŽS & ZF \\
\hline
\end{tabular}

Slika 3: Prikazi z najboljšimi povprečnimi ocenami $(n=223)$ (izdelala: Jana Kozamernik) 


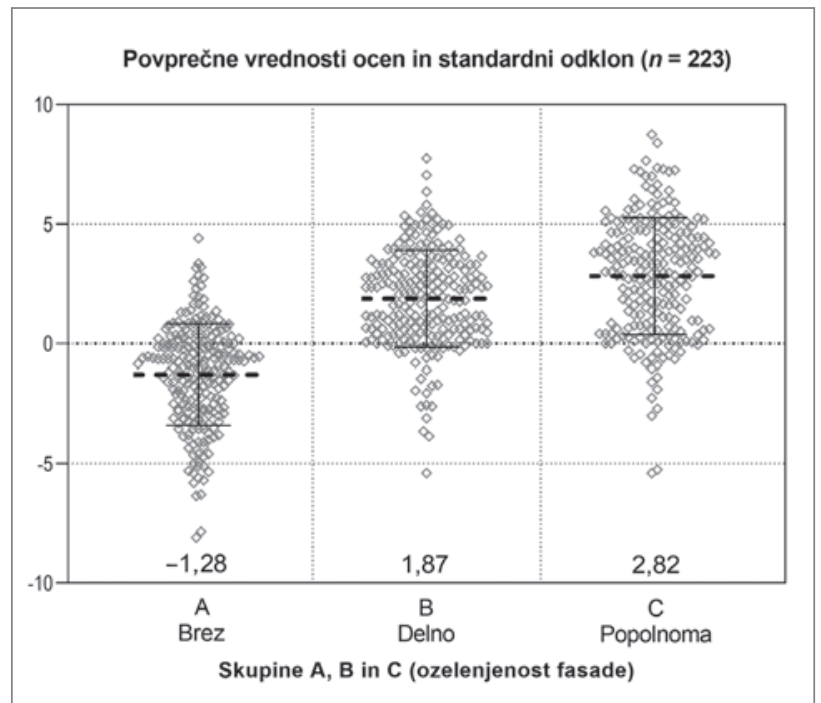

Slika 4: Povprečje ocen in standardni odklon slik, razvrščenih v skupine A (brez ozelenjene fasade), B (delno ozelenjena fasada) in C (polno ozelenjena fasada) v celotnem vzorcu $(n=223)$ (izdelala: Jana Kozamernik)

brazbeno raven in $28,3 \%$ magisterij ali VII izobrazbeno raven. Med njimi je bilo 32,2 \% anketirancev s končano V. stopnjo izobrazbe, $\mathrm{v}$ manjšsih deležih pa so bili zastopani anketiranci s IV stopnjo (5,4\% anketirancev) in nižjo, do III stopnje izobrazbe (5,4 \% anketirancev) ter anketiranci z VIII, najvišjo stopno izobrazbe (4,5\%). Glede na tip naselja ali okolje bivanja anketirancev smo po zastopanosti v anketi zajeli največ ljudi, iz urbanega okolja (28,3\%), sledili so anketiranci iz manjših podeželskih naselij $(23,3 \%)$, mestnih središč $(21,5 \%)$ in primestnega območja (20,6\%), najmanj anketirancev pa je bilo s podeželja $(6,3 \%)$.

\subsection{Prednostne izbire na podlagi prikazanih slik}

Frekvenčne porazdelitve odgovorov anketirancev o posameznih prikazih $\mathrm{v}$ anketi kažejo na trend gibanja ocen $\mathrm{v}$ negativni ali pozitivni smeri. Na podlagi izračuna povprečij smo pridobili oceno posameznega prikaza (Slika 1) in standardne odklone povprečnih ocen, ki kažejo, da gre za dokaj veliko razpršenost ocen ali odgovorov (SD 3,1-4,3).

Pri razvrstitvi vizualnih dražljajev od najbolj pozitivno ocenjenih (privlačnih) do negativno ocenjenih (neprivlačnih) ugotovimo, da so med 10 najmanj privlačnimi slikami (preglednica 1) z izjemo ene slike vse tipa prikaza A (različica prostora brez ozelenjene fasade). Vključujejo zunanje prostore nakupovalnih središč (dva najslabše ocenjena prikaza), stanovanjskih območij (dva prikaza), javnih stavb (3 prikazi) in uličnega ambienta. Med najslabše ocenjenimi prostori se je na 10 . mesto uvrstil prikaz predprostora nakupovalnega središča z delno ozelenjeno čelno fasado (tip žive stene). Najslabše ocenjene slike so prikazane na sliki 2.
Rezultati pregleda slik z najvišjimi povprečnimi ocenami kažejo na visoko vrednotenje ozelenjenega odprtega prostora - med desetimi najbolje ocenjenimi prikazi je uvršcenih pet prikazov iz sklopa $\mathrm{C}$ (polno ozelenjena fasada) in pet iz sklopa $\mathrm{B}$ (delno ozelenjena fasada). Glede na tip prikazanega odprtega prostora gre za slike stanovanjskih območij, prostorov ob javnih stavbah in druge odprte prostore s različnimi vrstami rabe (igrišče, trg) (Preglednica 2). Najbolje ocenjene slike so prikazane na slik 3 , med bolj privlačnimi prikazi so bile tudi tri 3D-vizualizacije stanovanjskih blokov z ozelenjeno fasado.

\subsection{Stopnja ozelenjenosti fasad}

Na podlagi združitve prikazov v skupine glede na tri različice ozelenjenosti urbanega ambienta se je preverjalo vrednotenje prostora glede na prisotnost in odsotnost stenske ozelenitve ali kako obsežna je ta ozelenitev. Slika 4 prikazuje povprečne vrednosti vseh slik, razvrščenih v sklop A, B ali C, za celotni anketirani vzorec. Rezultati kažejo, da so ocene slik urbanih prostorov brez vertikalne ozelenitve (skupina A) v povprečju za 3,15 ocene nižje kot slike z vertikalno ozelenitvijo (skupini $\mathrm{B}$ in $\mathrm{C}$ ). $\mathrm{V}$ povprečju sta skupini B (delno ozelenjena fasada) in C (polno ozelenjena) ocenjeni kot privlačnejši, razlika je tudi med njunima srednjima vrednostma. Slike z bolj ozelenjenimi fasadami (C) so imele za 0,95 točke višjo povprečno oceno.

Ob pregledu vseh treh različic posameznega variantnega prikaza urbanih prostorov, ki smo jih vključili v anketo, ugotovimo, da je v vseh primerih 20 prikazanih prostorov ocena slike sklopa $A$ najnižja in ocena sklopa $C$ najvišja, pri čemer je razlika med ocenama sklopov $\mathrm{B}$ in $\mathrm{C} v \mathrm{v}$ nekaterih primerih minimalna. Na sliki 5 je primer enega od 20 obravnavanih odprtih prostorov, vključenih $\mathrm{v}$ anketo. Frekvenčne porazdelitve ocen posamezne slike kažejo na razlike med proučevanima vzorcema slovenskih in nizozemskih anketirancev, kljub tem razlikam pa je razviden podoben trend gibanja ocen $\mathrm{v}$ obeh državah.

\subsection{Primerjava glede na demografske značilnosti in različna vzorca}

Primerjava slovenskega in nizozemskega vzorca kaže, da so slovenski anketiranci slike na splošno ocenjevali z nižjimi ocenami od nizozemskih anketirancev. Pri 17 prikazih (od 60) je bila razlika v povprečni oceni slik nižja za več kot 1 oceno, pri dveh prikazih je bila razlika za več kot 2 oceni. Tudi glede na razvrstitev slik v sklope $A, B$ in $C$ se je pokazalo, da so bile slovenske ocene slik nižje, in sicer za 0,64 ocene za sklop A, za 0,63 ocene za sklop B in za 0,69 ocene za sklop C. Ob pregledu razlik med posameznimi prikazi ugotovimo, da se največje odstopanje pojavi v primeru uporabe znanih motivov (npr. primer znanega objekta na Nizozemskem, ki ga nizozemski anketi- 


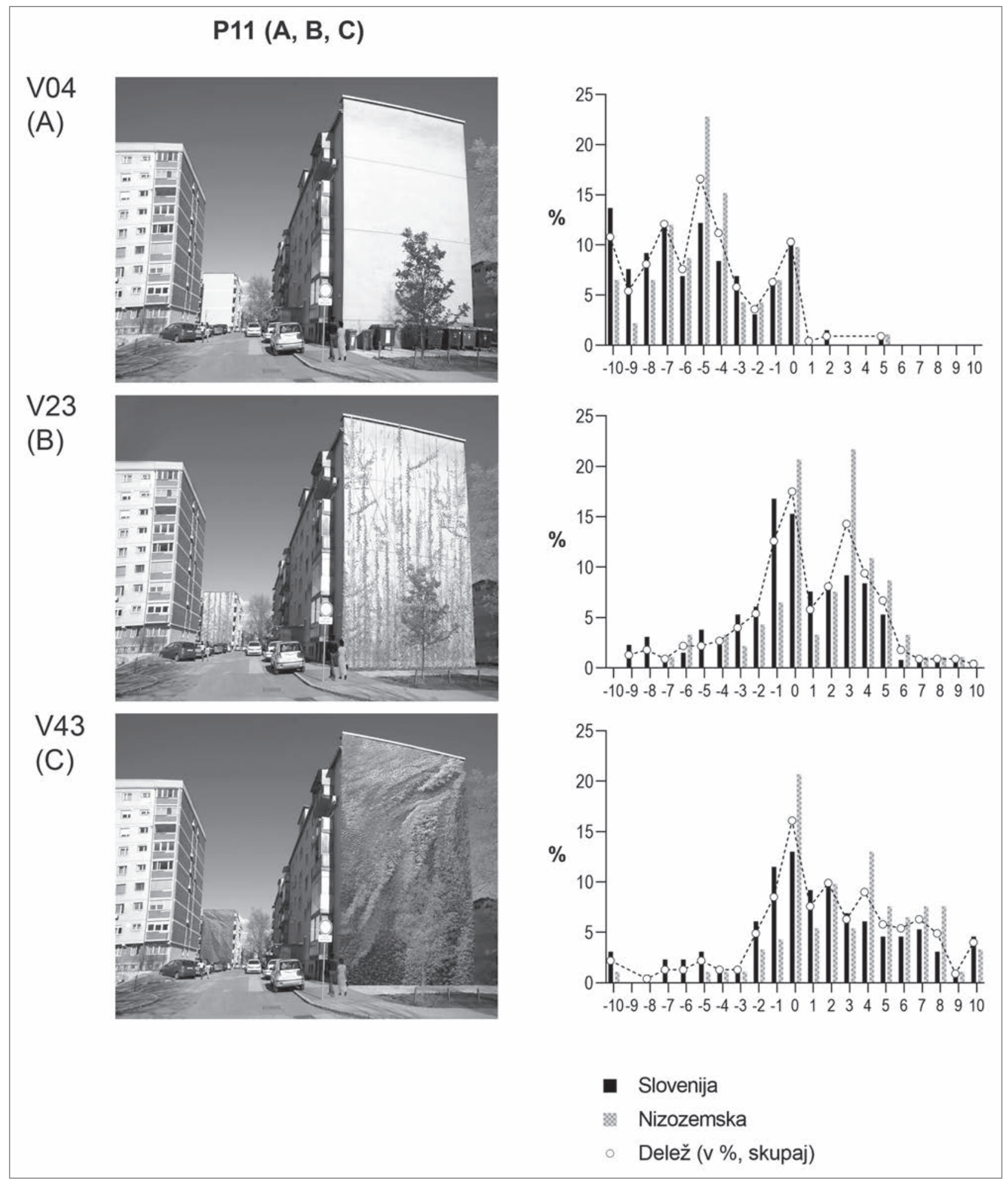

Slika 5: Različice prikazov (A, B, C) enega od 20 primerov in frekvenčne porazdelitve ocen primerov v obeh državah (izdelala: Jana Kozamernik)

ranci ocenjujejo višje v vseh variantnih prikazih). Prikazom sklopa A (brez ozelenjene fasade) so najslabše ocene podajali moški v slovenski anketi, pri nizozemski anketi so nižje ocene dajale ženske. Prikazom sklopov B in C (z delno oziroma popolnoma ozelenjeno fasado) so ženske v slovenski in nizozemski anketi dajale višje ocene od moških, razlike med ocenami spolov so večje pri nizozemskem vzorcu. Primerjava rezultatov med slovenskim in nizozemskim vzorcem glede na starostne skupine anketirancev kaže na večje razlike. V starostni skupini 26-35 let nizozemskega vzorca se povprečje ocen prikazov giblje okrog ocene 0. Sklepamo, da tej starostni skupini grajeni ambienti brez ozelenitve (fasade) niso niti privlačni niti nepri- 
P11 (A, B, C), povprečne vrednosti

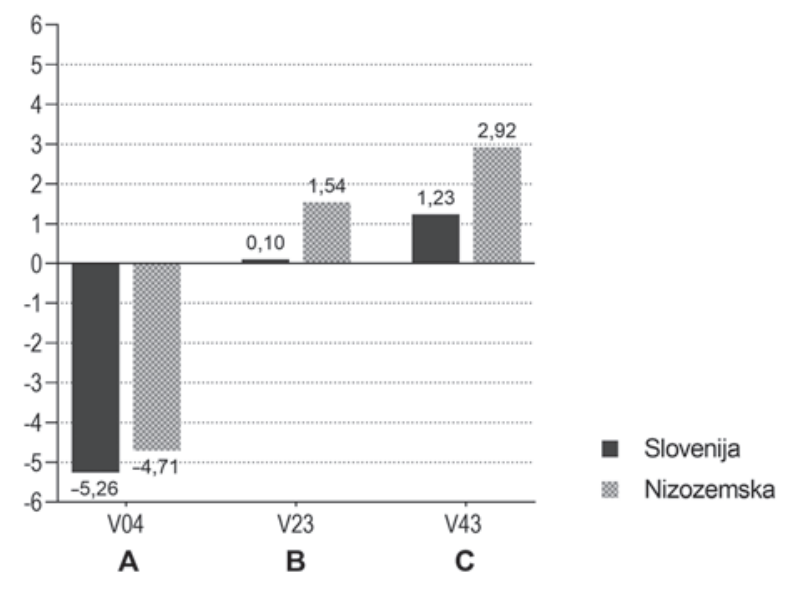

Slika 6: Povprečne ocene prikazov $(A, B, C)$ primerov v obeh državah (izdelala: Jana Kozamernik)

vlačni - so sprejemljivi. V nasprotju z njihovimi odgovori so ocene slovenskih anketirancev iste starostne skupine najnižje med vsemi proučevanimi starostnimi skupinami - sklepamo, da so ti ambienti njim najmanj privlačni. Najvišje ocene prikazom z ozelenjenimi fasadami so dajali slovenski anketiranci starostnega obdobja sredi in ob koncu delovne dobe (51-65 let) in nizozemski anketiranci delovne populacije, tj. starostne skupine med 36 in 50 let. Pri teh skupinah bi šlo lahko za večje zavedanje o pomembnosti stika z naravo v bivalnem okolju.

Razlika v vrednotenju odprtih prostorov se je pokazala tudi glede na kraj bivanja anketirancev. Predvsem slovenska populacija, ki živi v mestnih središčih, je v povprečju prikaze sklopa A slabše ocenila kot nizozemska, predvsem pa je zelo velika razlika pri oceni sklopov B in C. Prebivalci mestnih središč v Sloveniji so podali v primerjavi z anketiranci, ki živijo v drugih okoljih, najslabše ocene vsem sklopom prikazov (najnižje ocene glede na druge skupine). Anketiranci, ki živijo zunaj mestnih jeder, so prikaze brez ozelenjene fasade (A) ocenili manj negativno, hkrati pa tiste z ozelenjeno fasado $(B$ in $C) \mathrm{z}$ višjimi ocenami, podobno kot anketiranci v nizozemski raziskavi. Razlogi za rezultate so verjetno povezani z dejstvom, da se ozelenitev fasad na Nizozemskem pojavlja v večjem obsegu kot $\mathrm{v}$ Sloveniji, prebivalci mestnih središč $\mathrm{v}$ Sloveniji niso vajeni ozelenjenih fasad.

Opredelitve splošne in strokovne javnosti glede privlačnih prostorov kažejo, da je - ne glede na državo - strokovna javnost slike z ozelenjenimi fasadami (B in C) ocenjevala v povprečju za pol ocene bolje kot splošna javnost. Ob podrobnejši primerjavi ocen mlajše, študentske populacije, ki je sodelovala v anketi, deljene na študente arhitekturno-urbanističnih in sorodnih smeri (strokovno javnost) in študente drugih strok, se je pokazal podoben rezultat, saj je skupina strokovne javnosti prikaze z ozelenjenimi fasadami vrednotila z višjimi ocenami. Prikazi tipa A (brez ozelenjene fasade) skupina splošne javnosti ocenjuje manj negativno kot strokovna javnost, prikaze $\mathrm{v}$ sklopih $\mathrm{B}$ in $\mathrm{C}$ pa z nižjimi ocenami kot strokovna javnost. $\mathrm{Ob}$ dodatni primerjavi oziroma delitvi vzorca strokovne javnosti na ločen podvzorec študentov arhitekture in vzorec študentov urbanizma (in sorodnih smeri) pa rezultati kažejo, da so študentje urbanizma (in sorodnih smeri) tisti, ki prostore $\mathrm{z}$ ozelenjenimi fasadami ocenjujejo z opazno višjimi ocenami kot študentje arhitekture. Največja razlika med ocenami teh dveh skupin (za približno 1 oceno) se kaže pri prikazih A (brez ozelenjene fasade), ki so prikazovali realne slike urbanih okolij anketirani študentje urbanističnih (in sorodnih) smeri namreč ta okolja ocenjujejo z višjimi ocenami kot študentje arhitekture, kar lahko kaže na to, da se pojavljajo razlike v zaznavanju urbanih prostorov že v oblikovani skupini strokovne javnosti.

\subsection{Zaznavanje različnih tipov ozelenjenih fasad}

Ob pregledu vrednostnih ocen razvrščenih prikazov glede na tip ozelenjene fasade - zeleno fasado $(\mathrm{ZF})$ ali živo steno $(\check{Z} S)$ se je treba zavedati nekaterih omejitev glede na metodološki pristop in vizualne prikaze. Večina prikazov je zajela urbani ambient, ozelenjena fasada je bila tako vidna z oddaljene perspektive, ne od blizu. Na uporabljenih prikazih so vidne razlike med tipom zelene fasade ali žive stene, ni pa viden celotni detajlni ali tehnični sistem. Ocene privlačnosti posameznega tipa se obravnavajo na podlagi širšega prostorskega zaznavnega učinka. Rezultati kažejo, da imajo slike s tipom zelene fasade ali z uporabo popenjavk, ki izraščajo iz tal, v povprečju boljše ocene kot prikazi s tipom žive stene. Povprečna ocena zelene fasade je 2,65, žive stene pa 1,98. Čeprav se pri obeh tipih ozelenjenih fasad pojavljajo v povprečju primerljive najvišje povprečne ocene privlačnosti $(\max . \mathrm{ZF}=8,23, \check{Z} S=8,28)$ je povprečje zelene fasade višje od povprečja žive stene, saj so ocene zelene fasade manj razpršene, pri živi steni pa ocene segajo tudi do spodnjih negativnih vrednosti.

Podoben rezultat smo zaznali ob primerjavi prednostne izbire anketirancev glede na državo in spol anketirancev. Razlika ocen med obema tipoma ozelenjenih fasad je v nizozemskem vzorcu manjša kot v slovenskem. Rezultat je pričakovan, saj je tip zelenih fasad edini tip, ki se pojavlja na Slovenskem, žive stene pa se pojavljajo šele v novejšem času. Primerjava odgovorov obeh spolov v anketiranih državah kaže enako sliko bolje ocenjeni so prikazi s tipom zelene fasade. Pri moških je povprečna ocena teh tipov za 0,82 ocene višja kot tipov žive stene, pri ženskah pa je razlika nekoliko manjša, za 0,56 ocene. Rezultati primerjave starostnih skupin kažejo, da se zaznavanje glede tipov ozelenjenih fasad mlajših generacij ne razlikuje bistveno od starejših, anketiranci vseh starostnih skupin so zeleno fasado ocenili bolje kot živo steno, tudi v posamezni državi 


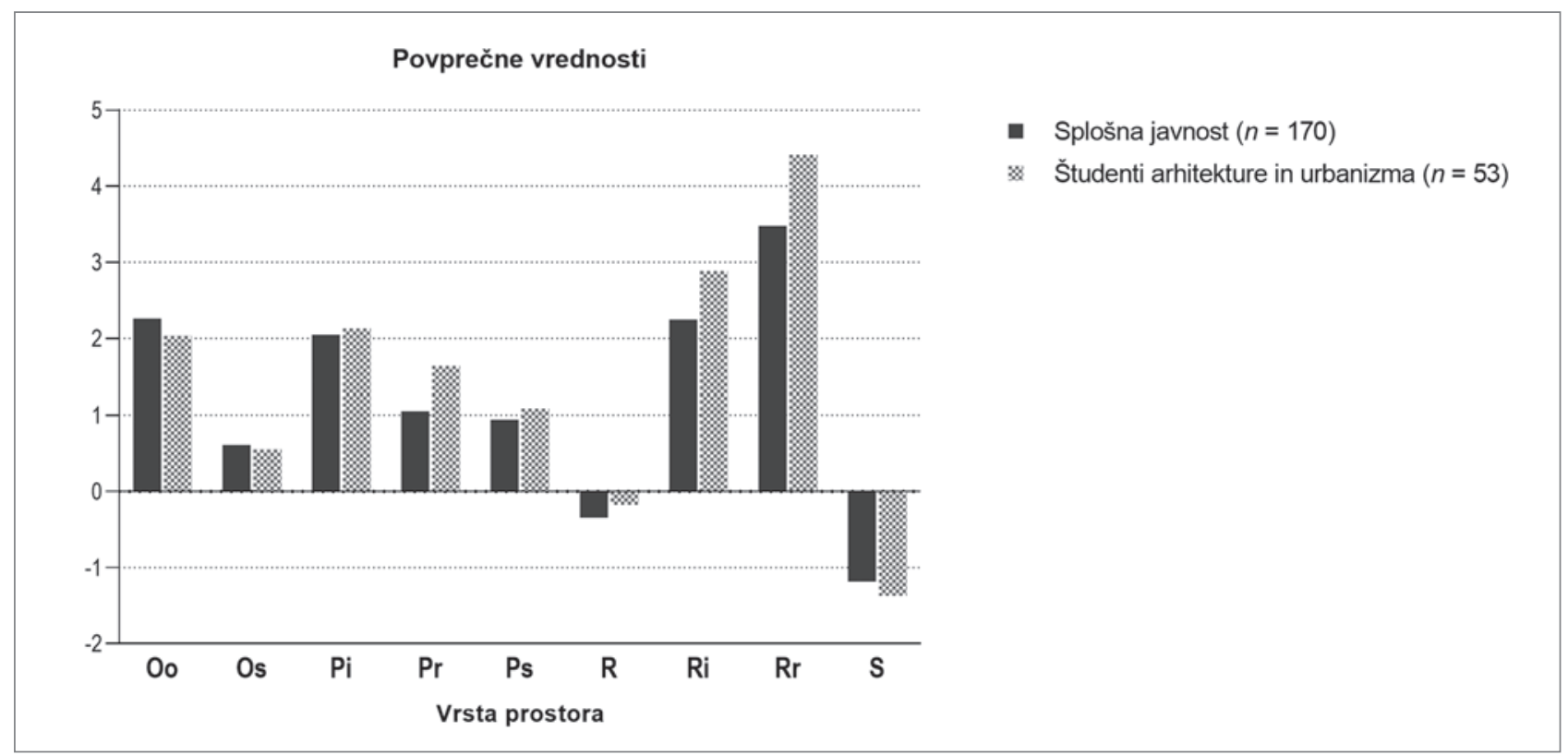

Slika 7: Povprečne ocene posameznih tipov prostorov glede na odgovore splošne javnosti in strokovne javnosti $(n=223)$ (izdelala: Jana Kozamernik)

in glede na okolje, $v$ katerem bivajo. Ne glede na najnižje ocene prebivalcev mestnih središč v Sloveniji se tudi njim zdijo bolj privlačni primeri z zelenimi fasadami. Podoben rezultat daje tudi primerjava med skupinama splošne in strokovne javnosti.

\subsection{Tipi urbanih prostorov}

V raziskavi je uporabljen majhen nabor tipov urbanih prostorov, saj je vanjo vključenih 20 primerov ambientov, zato lahko rezultate interpretiramo le kot mnenje anketirancev o konkretnih prikazih, težje pa te rezultate posplošimo. Primeri prostorov, ki jih ljudje dnevno uporabljajo, so bili razvrščeni v kategorije glede na funkcije prostorov in stavb (odprti prostor, $\mathrm{v}$ povezavi s stanovanjskimi, trgovskimi, javnimi stavbami). Ločeno od realnih primerov (fotografiranih) smo analizirali prikaze, ki izhajajo iz 3D-vizualizacij (izdelanih v realistični tehniki). Med prikazi realnih situacij so bili anketirancem najbolj privlačni javni odprti prostori z različnimi vrstami rabe, kjer se ljudje pogosto zadržujejo (npr. trg, igrišče), in prostori ob javnih stavbah, najmanj pa prikazi trgovsko-poslovnih območij. Med bolj privlačnimi primeri lahko izpostavimo 3D-vizualizacijo sodobnega stanovanjskega bloka, ki je bila ocenjena $\mathrm{z}$ visokimi ocenami.

Na podlagi primerjave ocen med državama je razvidno, da je kljub splošno nižjim ocenam slovenskih anketirancev v celotni anketi $\mathrm{v}$ primeru vrednotenja urbanih javnih odprtih prostorov (npr. trg, igrišče) povprečje ocen slovenske in nizozemske ankete skoraj enako. Splošna javnost, zajeta v raziskavi, v primerjavi s strokovno javnostjo višje vrednoti vse vključene primere javnih odprtih prostorov (predvsem tiste $\mathrm{z}$ večnamensko funkcijo ali kjer se ljudje zadržujejo, npr. trgi, igrišča), hkrati pa z opazno nižjimi ocenami od strokovne javnosti ocenjujejo stanovanjska območja in vse primere, prikazane kot 3D-vizualizacije (Slika 7). Rezultati kažejo še, da so urbani odprti prostori najbolje ocenjeni po mnenju prebivalcev urbanih območij, manj pa po mnenju prebivalcev podeželskih območij. Najbolj negativno so bili ocenjeni primeri prostorov poslovno-trgovinskih središč.

\section{Razprava}

Na zaznavanje urbanih okolij imajo velik vpliv naravne prvine. Ozelenjene fasade kot rastlinski gradnik in element zelene infrastrukture s svojo pojavnostjo na stavbah vplivajo na večjo privlačnost urbanega prostora. Vrednotenje prostorov z ozelenjenimi fasadami kot bolj privlačnih od tistih brez ozelenitve je dalo pričakovan rezultat tudi glede na dosedanje raziskave o pomenu naravnih prvin v bivalnem okolju in pozitivnem vplivu rastlin na zaznavanje prostora. Ugotovili smo, da se zaznavanje istega prostora spremeni, če so v njem ozelenjene fasade.

Dojemanje prostora (na podlagi proučevanega vrednotenja ozelenjenih fasad kot gradnikov urbanega prostora) je odvisno tudi od socialno-demografskih značilnosti anketirancev. Ugotovljene so bile razlike v ocenah skupin različnih starostnih obdobij v proučevanih državah, še posebej v skupini mladih in starejših, kar lahko nakazuje na nekatere kulturološke razlike med državama. Ob večjih odstopanjih rezultatov anketirancev mestnih središč se pojavlja vprašanje, zakaj slovenski anketiranci v primerjavi z nizozemskimi veliko bolj kritično ocenjujejo urbane ambiente. Nizka ocena te skupine anketirancev za vse 
prikazane sklope (najnižje ocene glede na druge skupine) kaže, da so morda ti ljudje tudi bolj kritični do bivalnega okolja na splošno. $\mathrm{V}$ tem pogledu bi bilo smiselno raziskavo razširiti in pridobiti informacije drugih držav tako $\mathrm{v}$ obravnavi teh gradnikov fasad kot splošno zelenih prvin v urbanem okolju ter se osredotočiti na primerjavo med prebivalci mest in drugih bivalnih okolij ter dodatno vključevati v raziskave tudi mnenje strokovne javnosti.

Ena od ključnih ugotovitev je pomembnost količine rastlin, ne le njihova prisotnost $\mathrm{v}$ urbanem kontekstu. Na podlagi rezultatov namreč lahko sklepamo, da je javno mnenje naklonjeno večjemu deležu zelenja v urbanem okolju. Ob tem je treba poudariti, da so rezultati tesno povezani z uporabljenimi vizualnimi prikazi. Ti so prikazovali realistične scenarije izvedbe ozelenjenih fasad - $\mathrm{z}$ različno stopnjo ozelenitve, a vedno $\mathrm{v}$ smiselnem obsegu glede na arhitekturo, na katero se vežejo, ustrezno stanje vzdrževanja in v času rasti rastlin. Večji vzorec anketirancev in vključevanje dodatnih slikovnih primerov, tudi manj urejenih ali privlačnih z vidika vzdrževanosti, bi lahko izboljšalo razumevanje odgovorov, ki niso nujno povezani z razmerjem količine zelenja, ampak tudi z vrednotenjem teh prvin glede na njihovo stanje. Vseeno lahko na podlagi rezultatov sklepamo, da ljudje na splošno visoko vrednotijo bolj ozelenjene urbane ambiente, kar je ključno z vidika urbanističnega oblikovanja in smernic za načrtovanje teh prostorov.

Mnenje anketirancev o prednostni izbiri glede tipov ozelenjenih fasad se je smiselno obravnavalo v povezavi z rezultati raziskave iz leta 2011 (White in Gatersleben, 2011), katere rezultati so nakazali, da imata velik vpliv na mnenje anketirancev uporabljeni sistem in izbor rastlin. Ugotovitve naše raziskave kažejo, da je ljudem bolj privlačen tradicionalni tip zelene fasade in da so do sodobnih sistemov (živa stena) bolj zadržani. Treba pa se je zavedati, da raziskava posameznih tipov ni podrobno obravnavala, vendar so bili glede na merilo prikazov med sistemi ali posameznimi tipi vseeno vidne razlike. Sklepamo lahko, da bi glede na te ugotovitve raziskave ljudje $\mathrm{v}$ urbanih okoljih tip zelene fasade sprejeli $\mathrm{z}$ večjim odobravanjem ali z manjšim odklonom.

Za proučevanje urbanih okolij bi bilo treba dosegati večjo raznovrstnost in nabor prikazov posameznih ambientov, kar zaradi metodologije ni bilo mogoče in kaže na pomanjkljivost te raziskave. Ta se je prednostno posvečala variantnim prikazom okolij in je bila omejena $\mathrm{v}$ številu slik zaradi upoštevanja še sprejemljivega obsega vprašalnika. Kljub omejenemu naboru prikazov urbanih prostorov lahko ugotovimo, da imajo v zaznavanju uporabnikov velik pomen odprti javni prostori in območja ob javnih stavbah. Gre za prostore družabnega dogajanja in druženja ter običajno oblikovane - načrtovane ureditve odprtega prostora. Do prostorov v neposredni navezavi na stanovanjske objekte, tj. stanovanjskih območij, se anketiranci opredeljujejo bolj kritično. Najslabše ocenjeni zunanji prostori v območjih trgovinskih centrov pa so verjetno z vidika uporabnika kakovostno siromašna okolja. Glede na rezultate raziskave lahko opozorimo tudi, naj se pri izvajanju podobnih raziskav pri uporabi realnih motivov upošteva vidik (pre)poznavanja znanih realnih motivov in se $s$ tem vpliva na podane vrednostne ocene, hkrati je treba pri uporabi 3D-vizualizacij ambientov upoštevati vidik idealiziranih prikazov. Ugotovljeno je bilo, da ti vplivajo na ocene anketirancev. $V$ prihodnosti bi bilo smiselno $\mathrm{v}$ podobnih raziskavah omejiti prikaze na konkretne prostore, ki jih anketiranci ne poznajo. $\mathrm{V}$ raziskave $\mathrm{v}$ prihodnosti je treba zajeti tudi širši vzorec strokovne javnosti, tako študentske kot delovne populacije.

Raziskave, ki se ukvarjajo le z vizualnim zaznavanjem, bi bilo $\mathrm{v}$ prihodnosti smiselno nadgraditi s primerjalno metodologijo ali izvesti na način, ki bi vključeval tudi zaznavanje z drugimi čutili. Opomniti velja, da je omejitev te raziskave povezana $s$ pripravljenimi prikazi, delno pa tudi $s$ količino zajetih podatkov in njihovo uporabo pri podrobnejši analizi. Omejitve glede prikazov so povezane s številom slik in fizičnimi značilnostmi prostora na slikah ter presojo po prikazovanju stanja ozelenjene fasade so se pojavljale v sprejemljivih količinah in vedno v zadovoljivem vzdrževanem stanju. Poglavitni vzrok omejitev je bil obseg vprašalnika. Zaradi velike količine prikazov in načina spremljanja proučevanega gradnika je bil v anketo vključen majhen nabor posameznih tipov prostorov. Posledica te omejitve je majhna zanesljivost ugotovitev glede vrednotenja tipov urbanih prostorov. Kljub prilagoditvam obsega vprašalnika je bil zaznan velik osip v izpolnjevanju anket, veliko vprašalnikov je bilo izpolnjenih nepopolno (na primer le polovično), zato so bili izvzeti iz analize. Raziskava tako sloni tudi na omejeni zanesljivosti rezultatov glede na posamezne podskupine anketirancev, na primer manjšega števila anket zadevne skupine (npr. najstarejše populacije in glede na bivalno okolje tistih, ki živijo v ruralnem okolju). Kot manjša omejitev z vidika proučevanja kulturoloških razlik pa je primerljivost raziskave na mednarodni ravni, saj je raziskava omejena na razlike med Slovenijo in Nizozemsko in ne vključuje drugih držav.

\section{Sklep}

Razumevanje odnosa ljudi do urbanega okolja in naravnih prvin v njem je ključno za opredelitev meril kakovosti in usmeritev pri načrtovanju teh prostorov. Raziskava osvetljuje vpliv ozelenjenih fasad na zaznavanje odprtih prostorov $\mathrm{v}$ urbanem okolju. Z metodološkega vidika se je v njej zajel širok krog anketirancev dveh evropskih držav, s pripravo raziskovalnega materiala pa se omogočata povezava in uporaba $\mathrm{z}$ drugimi metodologijami v prihodnosti. Na podlagi ugotovitev o vplivu zelenih sten na zaznavanje urbanih ambientov lahko sklepamo 
o veliki pomembnosti zelene infrastrukture v zaznavanju uporabnikov prostora na splošno. Ugotovitve kažejo, da bi bilo smiselno več pozornosti nameniti tudi drugim raziskavam zelene infrastrukture v mestih, $\mathrm{v}$ okviru proučevanega gradni$\mathrm{ka}$ (ozelenjenih fasad) pa njihovo vlogo v primerjavi z drugimi elementi zelenega sistema. $V$ konkretnih odločitvah za njihovo uporabo je treba pozornost posvetiti lokacijam in arhitekturni sprejemljivosti ter upoštevanju okoljske odgovornosti. Ključno je, da se načrtovalci urbanega prostora zavedajo pomena prisotnosti zelenih prvin in jih obravnavajo kot ene od nosilcev prostorske kakovosti, tako v novo nastajajočih kot $\mathrm{v}$ obstoječih in manj privlačnih urbanih okoljih.

Jana Kozamernik

Urbanistični inštitut Republike Slovenije, Ljubljana, Slovenija

E-naslov: jana.kozamernik@uirs.si

Martin Rakuša

Oddelek za nevrološke bolezni, Univerzitetni klinični center Maribor,

Maribor, Slovenija

E-naslov: ris101@gmail.com

Matej Nikšič

Urbanistični inštitut Republike Slovenije, Ljubljana, Slovenija

E-naslov:matej.niksic@uirs.si

\section{Zahvala}

Raziskava je bila v izdelana v okviru projekta H5-8287 Urban Vertical Green 2.0: Vertical greening for living cities - co-creative innovation for the breakthrough of an old concept, ki ga je finančno podprla Javna agencija za raziskovalno dejavnost RS iz državnega proračuna. Projekt je del skupne evropske pobude (Joint Programming Initiative Urban Europe) v okviru razpisa Sustainable Urbanization Global Iniative (SUGI) Food-Water-Energy Nexus; skrajšano ERA-NET Cofund SUGI.

Avtorji se zahvaljujejo študentom in njihovim mentorjem fakultete Saxion University of Applied Sciences - School of Governance, Law and Urban Development (stadsLAB, študijsko leto 2018/19) za diseminacijo anketnega vprašalnika na Nizozemskem, Studiu Krištof arhitekti d.o.o. za dovoljenje za uporabo dveh vizualizacij v anketi raziskave ter Rebeki Falle za pomoč pri statistični obdelavi podatkov.

\section{Viri in literatura}

Bell, P. A. (2001): Environmental psychology. Belmont, Thomson-Wadsworth.

Bustami, R. A., Belusko, M., Ward, J., in Beecham, S. (2018): Vertical greenery systems: A systematic review of research trends. Building and Environment, 146, str. 226-237. DOI: 10.1016/j.buildenv.2018.09.045

Carmona, M., Heath, T., Oc, T., in Tiesdell, S. (2003): Public places urban spaces: The Dimensions of urban design. Amsterdam - Tokyo, Architectural Press.

Černigoj, N. (2018): Spajanje narave in arhitekture: ozelenitev stavb za mesta prihodnosti. Mladina, 25(6), str. 54-56.
Fieandt, K. von (1966): The world of perception. Čikago, Dorsey Press.

Guan, X., Roös, P., in Jones, D. S. (2018): Biophilic city, vertical city, forest city? Towards an Architectree. V: IFLA 2018: Biophilic city, smart nation, and future resiliencee: Proceedings of the 55th International Federation of Landscape Architects World Congress 2018, str. 814-826. Singapur, IFLA.

Haesevoets, F. (2015): A city hall in Belgium to have a patchwork of mini green walls. Dostopno na: https://dzinetrip.com/a-city-hall-in-belgium-to-have-a-patchwork-of-mini-green-walls/ (sneto 2. 7. 2019).

Hayles, C., in Aranda-Mena, G. (2018): Well-being in vertical cities: Beyond the aesthetics of nature. V: Rajagopalan, P., in Andamonand, M. M. (ur.): 52nd International Conference of the Architectural Science Association, str. 331-338. Melbourne, The Architectural Science Association and RMIT University.

Internet 1: https://c2cvenlo.nl/en/city-hall-venlo/ (sneto 10. 7. 2019).

Internet 2: http://www.studiokristof.com/projects/pr5/index.html (sneto 15.4 . 2019).

Internet 3: http://www.studiokristof.com/projects/ts2/index.html (sneto 15.4 .2019 ).

Internet 4: https://venhoevencs.nl/projects/sportplaza-mercator/ (sneto 22. 7. 2019).

Jackson, J. B. (1994): A sense of place, a sense of time. New Haven, Yale University Press.

Jim, C. Y. (2015): Greenwall classification and critical design-management assessments. Ecological Engineering, 77, str. 348-362. DOI: 10.1016/j.ecoleng.2015.01.021

Köhler, M. (2008): Green facades - a view back and some visions. Urban Ecosystems, 11(4), str. 423-436. DOI: 10.1007/s11252-008-0063-x

Lu, Y., Sarkar, C., in Xiao, Y. (2018): The effect of street-level greenery on walking behavior: Evidence from Hong Kong. Social Science and Medicine, 208(2), str. 41-49. DOI: 10.1016/j.socscimed.2018.05.022

Mansor, M., Zakariya, K., Harun, N. Z., in Abu Bakar, N. I. (2017): Appreciation of vertical greenery in a city as public. Planning Malaysia Journal, 15(1), str. 117-128. DOI: 10.21837/pmjournal.v15.i6.227

Medl, A., Stangl, R., in Florineth, F. (2017): Vertical greening systems - A review on recent technologies and research advancement. Building and Environment, 125, str. 227-239. DOI: 10.1016/j.buildenv.2017.08.054

Montgomery, J. (1998): Making a city: Urbanity, vitality and urban design. Journal of Urban Design, 3(1), str. 93-116. DOI: $10.1080 / 13574809808724418$

Nikšič, M. (2008): Povezovanje urbanih mikroambientov $v$ prepoznavno celoto: strukturiranost odprtega javnega prostora mesta $v$ miselni sliki uporabnikov. Doktorska disertacija. Ljubljana, Univerza v Ljubljani, Fakulteta za arhitekturo.

O'Hare, A. J., Atchley, R. A., in Young, K. M. (2017): Valence and arousal influence the late positive potential during central and lateralized presentation of images. Laterality, 22(5), str. 541-559.

DOI: 10.1080/1357650X.2016.1241257

Passini, R. (1992): Wayfinding in architecture. New York, Van Nostrand Reinhold.

Perini, K., in Rosasco, P. (2013): Cost-benefit analysis for green façades and living wall systems. Building and Environment, 70(12), str. 110-121. DOI: 10.1016/j.buildenv.2013.08.012

Pfoser, N. (2016): Fassade und Pflanze, Potenziale einer neuen Fassadengestaltung. Doktorska disertacija. Darmstadt, Technische Universitat Darmstadt. 
Punter, J. (1991): Participation in the design of urban space. Landscape Design journal, 200, str. 24-27.

Rapoport, A. (1977): Human aspects of urban form. Towards a man-environment approach to urban form and design. Oxford, Pergamon.

Rasmussen, S. E. (2001): Experiencing architecture. Cambridge, MA, MIT Press.

Relph, E. (1976): Place and placelessness. London, Pion Ltd and Sage Publications Ltd.

Strumse, E. (1994): Environmental attributes and the prediction of visual preferences for agrarian landscapes in Western Norway. Journal of Environmental Psychology, 14(4), str. 293-303.

DOI: $10.1016 / 50272-4944(05) 80220-8$

Šuklje Erjavec, I., Balant, M., Kozamernik, J., in Nikšič, M. (2020): Zeleni sistem $v$ mestih in naseljih: Usmerjanje razvoja zelenih površin, priročnik. Ljubljana, Ministrstvo za okolje in prostor, Direktorat za prostor, graditev in stanovanja.

Tsantopoulos, G., Varras, G., Chiotelli, E., Fotia, K., in Batou, M. (2018): Public perceptions and attitudes toward green infrastructure on buildings: The case of the metropolitan area of Athens, Greece. Urban Forestry and Urban Greening, 34(June), str. 181-195.

DOI: 10.1016/j.ufug.2018.06.017

Van Renterghem, T. (2019): Towards explaining the positive effect of vegetation on the perception of environmental noise. Urban Forestry \& Urban Greening, 40, str. 133-144. DOI: 10.1016/j.ufug.2018.03.007

Vogelnik, B. (2013): Predlog kako rekonstruirati roške stolpnice. AR. Arhitektura, raziskave, 13(1), str. 102-107.

White, E. V., in Gatersleben, B. (2011): Greenery on residential buildings: Does it affect preferences and perceptions of beauty? Journal of Environmental Psychology, 31(1), str. 89-98. DOI: 10.1016/j.jenvp.2010.11.002

Wong, N. H., Kwang Tan, A. Y., Chen, Y., Sekar, K., Tan, P. Y., Chan, D., idr. (2010a): Thermal evaluation of vertical greenery systems for building walls. Building and Environment, 45(3), str. 663-672.

DOI: 10.1016/j.buildenv.2009.08.005

Wong, N. H., Kwang Tan, A. Y., Tan, P. Y., Sia, A., in Wong, N. C. (2010b): Perception studies of vertical greenery systems in Singapore. Journal of Urban Planning and Development, 136(4), str. 330-338.

DOI: 10.1061/(ASCE)UP.1943-5444.0000034 